\title{
IMPLEMENTASI INTERNET OF THINGS PADA SISTEM INFORMASI PELACAKAN KENDARAAN BERMOTOR MENGGUNAKAN GPS BERBASIS WEB
}

\author{
(Implementation of Internet of Things on Web-Based Motor Vehicle Tracking \\ Information System Using GPS)
}

\author{
Abdul Chalel Rahman, I Wayan Agus Arimbawa*, dan Andy Hidayat Jatmika \\ Prodi. Teknik Informatika, Fakultas Teknik, Universitas Mataram \\ Jl. Majapahit 62, Mataram, Lombok NTB, INDONESIA \\ Email: abdulchalelrahman@gmail.com, arimbawa@unram.ac.id, andy@unram.ac.id
}

\begin{abstract}
The research of motor vehicle tracking system using GPS have been done by some researchers. However, those researches still have problems, such as the location's accuracy, data transmission that is still manual using SMS, and systems that have not been integrated with the web server. This research applies the concept of Internet of Things on a vehicle system device consisting of four parts. There are an Arduino Uno R3 microcontroller as part of control, GYNEO6MV2 GPS module providing position information, SIM900A GSM/GPRS module used to send or receive data from server, and web-based information system used to monitor position of vehicle. From the results it can be concluded that GPS Tracker device that was designed has ran well and produced an average error difference of 2,457 meters.
\end{abstract}

Keywords: GPS Tracker, Vehicle tracking system, GPS, Arduino Uno R3, SIM900A, NEO6MV2

*Penulis korespondensi

\section{Pendahuluan}

Lomata Tour and Travel merupakan perusahaan penyedia perjalanan wisata yang ada di pulau Lombok, NTB yang mana salah satu layanan utamanya adalah rent car. Lomata saat ini masih menggunakan cara-cara lama yang konvensional dan manual dalam pelayanan penyewaan kendaraan. Beberapa contohnya yaitu pada proses penyewaan kendaraan yang hanya dengan menyerahkan KTP atau paspor, serta dalam pembuatan laporan penyewaan yang sering tidak tersimpan dengan baik karena masih bersifat tulis manual. Ditambah lagi dengan sistem pelacakan yang belum diterapkan pada kendaraan yang disewakan, sehingga perusahaan akan mengalami kesulitan dalam melacak posisi kendaraan yang dibawa oleh penyewa.

Sistem pelacakan kendaraan adalah rangkaian sistem yang dipasang pada kendaraan agar dapat dilacak oleh pemilik kendaraan atau pihak ketiga lainnya. Sistem pelacakan kendaraan modern umumnya menggunakan perangkat GPS untuk menentukan lokasi kendaraan. [1]. GPS (Global Positioning System) merupakan sistem navigasi berbasis satelit yang dapat menunjukkan lokasi dan informasi waktu di segala kondisi cuaca di mana pun pada permukaan bumi selama mendapat jangkauan dari minimal empat buah satelit GPS [2]. Penerapan GPS ini juga dapat diimplementasikan juga menggunakan konsep Internet of Things (IoT) dengan memanfaatkan perkembangan konektivitas internet [3]. Salah satu perangkat yang dapat mendukung sistem loT adalah Arduino yang merupakan pengendali mikro single-board yang bersifat open-source yang mampu mengendalikan beberapa modul seperti modul GPS untuk mendapatkan koordinat lokasi latitude dan longitude dari satelit GPS yang digunakan untuk mengetahui posisi dari suatu objek. Selain modul GPS, Arduino juga dapat mengendalikan modul GPRS yang berfungsi untuk mengirim data koordinat lokasi ke sebuah web server melalui jaringan internet. Untuk melihat data koordinat lokasi yang dikirim oleh perangkat sistem pelacakan kendaraan, maka dibutuhkan sebuah sistem informasi yang akan menampilkan lokasi dari kendaraan yang telah dipasangkan alat GPS.

Konsep IoT pada sistem pelacakan kendaraan bermotor ini dapat diimplementasi pada perusahaan Lomata Tour and Travel untuk membantu pihak Lomata dalam melakukan pelacakan terhadap kendaraan sewaan sehingga mengurangi kemungkinan kehilangan aset perusahaan baik berupa mobil maupun motor.

\section{TINJAUAN PUSTAKA}

Sebelumnya telah banyak dilakukan penelitian tentang sistem pelacakan kendaraan menggunakan 
GPS dan sejenisnya. Penelitian terdahulu dilakukan dengan menggunakan Mikrokontroler ATMEGA8535, modem GSM, dan modul GPS EG-T10 menghasilkan sebuah perancangan sistem pelacakan lokasi via SMS yang dibangun atas 2 sisi, yaitu sisi pelacak dan sisi yang dilacak [1]. Penelitian serupa juga telah dilakukan dengan menggunakan Mikrokontroler ATMEGA66PA, modul GPS Neo6m, dan modul GSM SIM900 yang diintegrasikan dengan situs Orange-Trace menghasilkan selisih akurasi error dari modul GPS yang digunakan sekitar 0,23-0,25 untuk koordinat latitude dan 0,02-0,05은 untuk koordinat longitude. [2]

Penelitian selanjutnya yang mendukung penelitian sebelumnya yaitu penelitian tentang sistem keamanan kendaraan berbasis GPS yang menggunakan Mikrokontroler ATMEGA 328, modul GPS Ublox 6mv2, modem GSM, dan aplikasi Google Maps pada smartphone [4]. Penelitian ini dapat memberikan posisi dari kendaraan yang hilang dengan mengirim pesan SMS yang berupa link Google Maps kepada pemilik kendaraan.

Penelitian serupa juga telah dilakukan dengan menggunakan Mikrokontroler Arduino MEGA 2560 dan modul GPS Sheild yang dapat mengontrol jarak jauh dengan menggunakan SMS seperti tracking posisi kendaraan dan mampu mematikan mesin kendaraan [5].

Dari penelitian-penelitian di atas, dapat disimpulkan bahwa terdapat 3 bagian penting dalam membangun sebuah perangkat sistem pelacakan kendaraan menggunakan GPS. Bagian pertama adalah sebuah mikrokontroler yang digunakan untuk pengendali utama dari sistem tersebut. Kemudian bagian yang kedua adalah modul GPS. Modul ini berfungsi sebagai penerima data koordinat latitude dan longitude dari satelit GPS. Tanpa modul ini akan terasa mustahil sistem akan berhasil dijalankan. Kemudian bagian yang terakhir adalah perangkat modul GSM/GPRS yang berfungsi sebagai pengirim data ke server / pengguna.

Untuk memudahkan pengguna dalam melakukan pelacakan terhadap kendaraan, dibutuhkan sebuah sistem yang dapat memberikan informasi dengan cepat dan akurat. Dalam penelitian yang telah dilakukan sebelumnya penerimaan informasi posisi kendaraan masih bersifat manual, di mana pengguna harus melakukan permintaan lokasi terhadap perangkat GPS menggunakan SMS dengan format yang telah ditentukan sebelumnya. Hal ini tentu akan merepotkan pengguna dalam melakukan pelacakan. Pada salah satu penelitian juga menggunakan server dan situs Orange-Trace dalam memantau kendaraan yang mana server tersebut sulit untuk dikembangkan dan privasi dari pengguna pun belum terjamin.

Berdasarkan tinjauan pustaka tersebut di atas, maka dapat dirancang sebuah perangkat sistem pelacakan kendaraan bermotor yang menggunakan sebuah mikrokontroler Arduino Uno R3, modul GPS GY-Neo6mv2, dan modul GSM/GPRS SIM900A. Pada sisi pengguna, akan dibangun sebuah sistem informasi berbasis web yang akan memudahkan pengguna dalam melacak dan memantau aktivitas dari posisi sebuah kendaraan. Pada web ini juga akan dilengkapi dengan fitur tracking dan fitur pengaturan jeda interval pengiriman data dari perangkat GPS.

\subsection{Internet of Things (IoT).}

Internet of Things (IoT) pertama kali diperkenalkan oleh Kevin Ashton pada tahun 1999. Meski telah diperkenalkan sejak 19 tahun yang lalu, hingga kini belum ada sebuah konsensus global mengenai definisi IoT. Namun secara umum konsep loT diartikan sebagai sebuah kemampuan untuk menghubungkan objekobjek cerdas dan memungkinkannya untuk berinteraksi dengan objek lain, lingkungan maupun dengan peralatan komputasi cerdas lainnya melalui jaringan internet. loT dalam berbagai bentuknya telah mulai diaplikasikan pada banyak aspek kehidupan manusia [3]. Meski telah mulai diaplikasikan pada banyak bidang kehidupan sehari-hari, namun belum ada satu definisi yang baku dari loT. Secara sederhana konsep IOT dapat digambarkan dengan bentuk arsitektur seperti ditunjukkan pada Gambar 1.

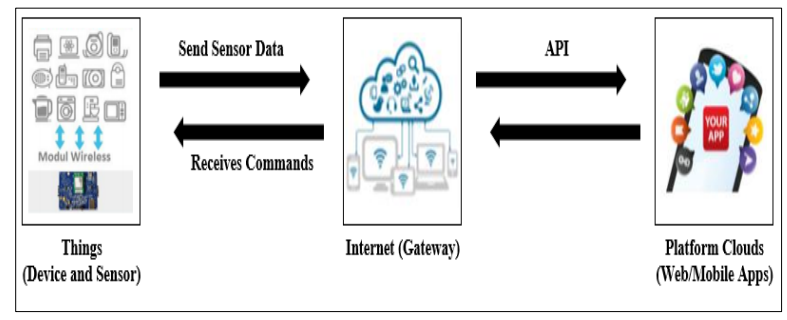

Gambar 1 Arsitektur Internet of Things

\subsection{Global Positioning System (GPS)}

Global Positioning System (GPS) merupakan suatu sistem navigasi radio berbasis satelit yang dikembangkan oleh departemen pertahanan Amerika Serikat. Sistem GPS terdiri dari susunan 24 satelit mengorbit bumi dalam 6 orbit lingkaran. Satelit diatur sehingga setiap satu waktu ada 6 satelit dalam jangkauan penerima GPS [6].

GPS terdiri dari tiga bagian yaitu space segment (luar angkasa), ground segment (bumi) dan pengguna segment (pengguna). Bagian space segment (luar 
angkasa) yaitu satelit, terdapat 24 satelit aktif, 6 orbital planes dengan inklinasi (sudut antara bidang yang menjadi acuan dengan bidang yang diukur kemiringannya) sebesar $55^{\circ}$, dengan lama waktu 12 jam periode orbital, tinggi $20.000 \mathrm{~km}$, dengan kecepatan aproksimasi satelit sebesar $4 \mathrm{~km} /$ detik.

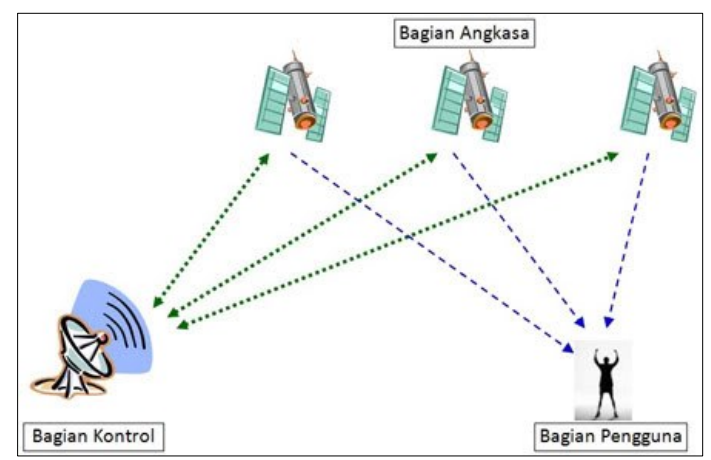

Gambar 2 Skema GPS

Salah satu modul GPS yang dapat digunakan untuk keperluan navigasi adalah Ublox NEO-6MV2. Modul GPS dengan tipe NEO-6MV2 merupakan modul GPS produksi Ublox AG, menggunakan komunikasi UART dengan protokol NMEA 0183 dengan pilihan nilai baudrate yang bervariasi antara lain 4800, 9600, dan 38400. Tegangan masukan yang dapat diberikan antara 3,3 - 5 Volt. Modul ini memiliki tingkat akurasi sekitar 2,5 meter -10 meter[2].

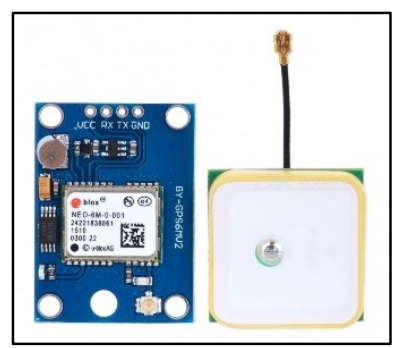

Gambar 3 Modul GPS GY-Neo6mv2

\subsection{Mikrokontroler Arduino Uno R3}

Arduino Uno R3 adalah papan pengembangan (development board) mikrokontroler yang berbasis chip ATmega328P. Disebut sebagai papan pengembangan karena board ini memang berfungsi sebagai arena prototyping sirkuit mikrokontroler. Dengan menggunakan papan pengembangan, pengguna akan lebih mudah merangkai rangkaian elektronika mikrokontroler dibanding jika memulai merakit ATMega328 dari awal di breadboard [7].

Arduino IDE adalah perangkat lunak IDE (Integrated Development Environment). Sebuah perangkat lunak yang digunakan untuk memudahkan pengembangan aplikasi mikrokontroler mulai dari menuliskan source program, kompilasi, upload hasil kompilasi, dan uji coba secara terminal serial [8].

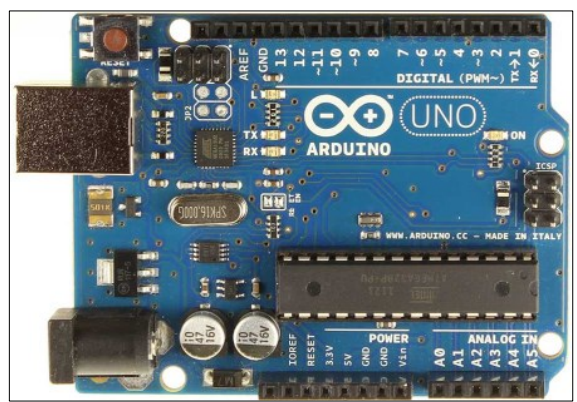

Gambar 4 Board Arduino Uno R3

\subsection{General Packet Radio Service (GPRS)}

General Packet Radio Service atau disingkat GPRS adalah teknologi paket data yang memungkinkan operator GSM untuk menyediakan layanan data nirkabel, seperti email dan akses internet. GPRS sering kali disebut sebagai teknologi 2.5G karena merupakan langkah awal bagi operator GSM menuju generasi ketiga (3G) dan langkah awal dimulainya layanan data nirkabel. GPRS mendukung kecepatan data maksimal untuk download sampai dengan $115 \mathrm{kbps}$, dengan kecepatan rata - rata antara 40-50 kbps[2].

SIM 900A GSM/GPRS Minimum System module adalah sistem minimum untuk modul SIM 900A dari SIMCOM. SIM900A sendiri merupakan modul GSM/GPRS Quad Band buatan SIMCOM. Modul GSM/GPRS ini dapat bekerja pada frekuensi 850/900/1800/1900 Mhz sehingga bisa digunakan pada jaringan GSM di berbagai negara. SIM 900A memiliki kemampuan GPRS mobile station class B yang artinya modul ini dapat terhubung dengan layanan GSM (telepon, SMS) atau layanan GPRS secara bergantian pada saat yang bersamaan. Jadi jika modul ini digunakan untuk melakukan layanan GSM semisal telepon, maka layanan GPRS-nya akan dihentikan untuk sementara dan akan dilanjutkan secara otomatis setelah layanan GSM-nya selesai digunakan.

\subsection{Web Service}

Web Service adalah suatu sistem perangkat lunak yang dirancang untuk mendukung interaction and interoperability antar sistem pada suatu jaringan. Web service digunakan sebagai suatu fasilitas yang menyediakan layanan (dalam bentuk informasi atau data) kepada sistem lain, sehingga dapat berinteraksi dengan sistem tersebut melalui layanan-layanan yang disediakan [9]. 


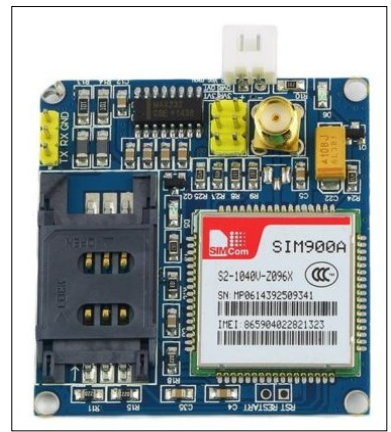

Gambar 5 Modul GSM/GPRS SIM900A

\subsection{Laravel}

Laravel adalah framework PHP yang menggunakan metode MVC (Model-View-Controller) agar mempermudah dalam pembangunan sistem karena hanya fokus mengatur serta membuat model, view, dan controller aplikasi saja dimana dikembangkan pertama kali oleh Taylor Otwell [10].

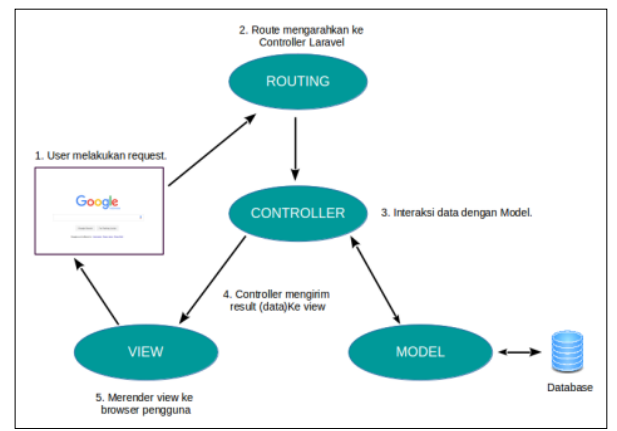

Gambar 6 Arsitektur MVC Laravel

Ketika berinteraksi dengan laravel, browser akan mengirimkan request kepada web server kemudian akan diteruskan ke sistem routing Laravel. Router laravel akan memproses request kemudian mengalihkannya ke masing-masing class dan method sesuai dengan request url yang telah didefinisikan sebelumnya. Oleh Controller, terjadi komunikasi dengan model jika diperlukan data yang berhubungan dengan database. Dalam beberapa kasus, controller akan melakukan render view yang nantinya akan dikonversi menjadi HTML dan dikirim kembali ke browser [11].

\section{Metode Peneltian}

\subsection{Rancangan Arsitektur Sistem}

Secara garis besar, rancangan sistem pelacakan kendaraan bermotor ini terbagi menjadi 3 bagian seperti konsep loT pada umumnya, bagian-bagian tersebut adalah:
1. Perangkat keras dari GPS Tracker yang dirakit menggunakan Arduino Uno R3, modul GPS, dan modul GPRS.

2. Internet sebagai gateway untuk menghubungkan perangkat keras ke web service.

3. Sistem informasi pelacakan kendaraan bermotor berbasis web sebagai aplikasi dari sisi pengguna.

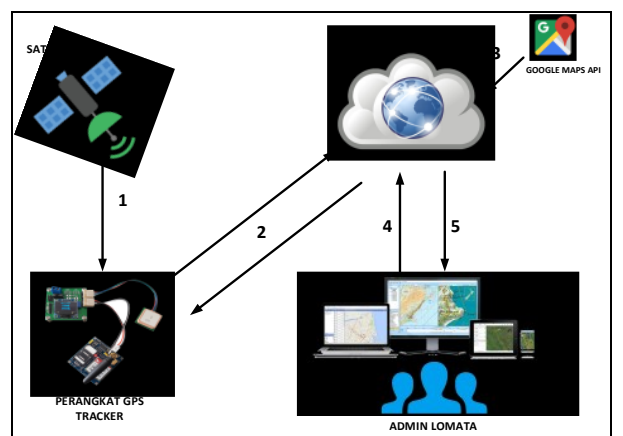

Gambar 7 Arsitektur Sistem Pelacakan Kendaraan Bermotor

Pada gambar arsitektur di atas, perangkat GPS akan menerima data koordinat latitude dan longitude dari satelit GPS melalui modul GPS Neo $6 \mathrm{mv} 2$. Kemudian perangkat GPS akan mengirim data tersebut ke web server dan akan mengambil data dari respon web server menggunakan koneksi internet dari modul GSM/GPRS SIM900A. Data yang diterima oleh server akan diolah dan ditampilkan pada web sistem informasi pelacakan kendaraan bermotor unutk diakses oleh pengguna.

\subsection{Rancangan Perangkat Keras}

Rancangan perangkat dari sisitem infor masi kendaraan bermotor menggunkan GPS dapat diihat pada Gambar 8.

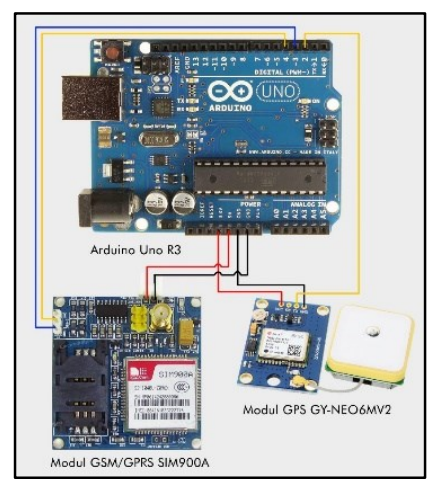

Gambar 8 Rancangan perangkat keras 
Gambar 8 terdapat Arduino Uno R3 yang dihubungkan dengan modul GPS GY-Neo6mv2 dan modul GPRS/GSM SIM900A menggunakan kabel jumper. Arduino Uno R3 digunakan sebagai otak dari alat yang akan dibuat yaitu berfungsi untuk menghubungkan sensor GPS yang ada pada modul GPS GY-Neo6MV2 ke satelit sehingga Arduino akan mendapatkan informasi berupa koordinat dari satelit yang kemudian akan dikirim ke web server melalui jaringan internet menggunakan modul GPRS/GSM SIM900A.

\subsection{Rancangan Perangkat Lunak}

Pada sistem pelacakan kendaraan bermotor menggunakan GPS yang akan dibangun terdapat 2 buah aplikasi yang akan dibangun, yaitu Control Application dan Sistem Informasi Pelacakan Kendaraan Bermotor.

\subsubsection{Rancangan Control Application.}

Control Application merupakan aplikasi yang akan dipasangkan pada Arduino dan digunakan untuk mengendalikan modul GPS dan modul GPRS/GSM untuk mengambil koordinat lokasi dari satelit kemudian mengirimkannya ke sistem informasi pelacakan kendaraan bermotor. Control Application akan dibangun dengan menggunakan bahasa pemrograman C. Rancangan dari Control Application dapat dilihat pada Gambar 9.

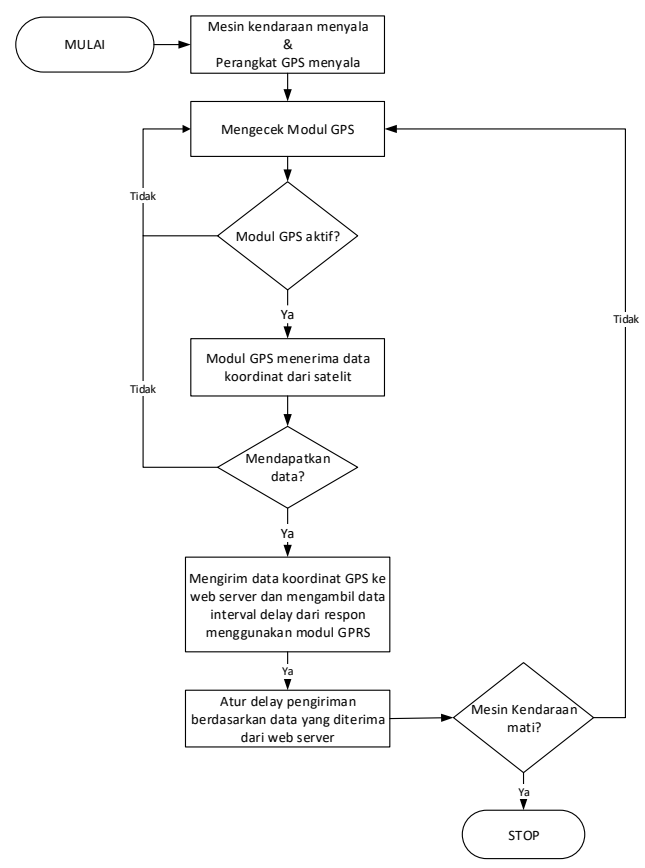

Gambar 9 Diagram alir control application
Gambar 9 merupakan diagram alir dari control application yang dimulai dengan proses perangkat GPS diaktifkan, kemudian Arduino akan melakukan proses pengecekan apakah sensor pada modul GPS sudah aktif atau belum. Apabila sensor telah aktif, maka perangkat akan menerima data koordinat latitude dan longitude dari satelit GPS. Kemudian perangkat GPS akan mengirim data koordinat tersebut ke web server menggunakan modul GSM/GPRS. Setelah melakukan pengiriman, perangkat akan mengambil data hasil respon dari proses pengiriman data yang dilakukan oleh perangkat GPS melalui internet menggunakan modul GSM/GPRS SIM900A.

Data yang diambil dari respons proses HTTP Request ini merupakan data update interval delay yang akan digunakan untuk mengatur jarak waktu pengiriman data yang dilakukan oleh perangkat GPS yang dapat diatur pada web sistem informasi kendaraan bermotor.

\subsubsection{Rancangan Sistem Informasi Pelacakan Kendaraan Bermotor}

Sistem Informasi Pelacakan Kendaraan Bermotor merupakan sebuah aplikasi berbasis web yang digunakan oleh admin dari perusahaan Lomata untuk memantau lokasi kendaraan yang telah dipasangkan alat GPS. Pada sistem informasi ini terdapat web service yang dibangun untuk menerima data kordinat dari perangkat GPS yang kemudian akan ditampilkan pada halaman web. Sistem ini akan dibangun menggunakan framework Laravel.

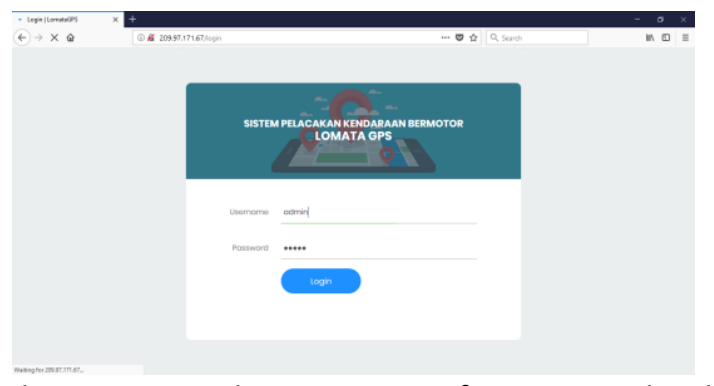

Gambar 10 Web Sistem Informasi Pelacakan Kendaraan Bermotor.

\section{Hasil dan PEMBahasan}

Pengujian terhadap sistem dilakukan dengan melakukan percobaan untuk melihat kemungkinan kesalahan yang terjadi dari setiap proses. Pada pengujian sistem ini dibagi dengan 2 tahap. Pada tahap pertama dilakukan pengujian terhadap fungsi dari perangkat GPS tracker yang telah dibuat. Kemudian pada tahap selanjutnya adalah pengujian terhadap 
fungsi dari sistem informasi pelacakan kendaraan berbasis web. Adapun pengujian sistem yang digunakan adalah metode Black Box untuk alat GPS dan metode kuesioner Mean Opinion Score (MOS) untuk web sistem informasi lomata GPS.

\subsection{Hasil Pengujian Perangkat GPS Tracker.}

Pada pengujian perangkat GPS Tracker ini digunakan metode pengujian black box yaitu menguji perangkat dari segi spesifikasi fungsional tanpa menguji desain dan kode program. Pengujian dimaksudkan untuk mengetahui apakah fungsi-fungsi dan keluaran sudah berjalan sesuai dengan harapan atau tidak. Berikut hasil pengujian yang telah dilakukan pada perangkat GPS Tracker.

\subsubsection{Pengujian Data Koordinat Modul GPS.}

Pada pengujian data koordinat modul GPS ini, alat tidak dalam keadaan bergerak dan dilakukan di ruangan terbuka dan cuaca dalam kondisi yang cerah. Pengujian yang dilakukan adalah mengukur akurasi posisi dari modul GPS dengan meletakkannya pada suatu titik koordinat yang telah ditentukan menggunakan perangkat GPS GARMIN seperti pada Gambar 11 dalam bentuk derajat koordinat yaitu pada posisi -8.580083 untuk titik latitude-nya, sedangkan untuk titik longitude-nya adalah 116.098860 .

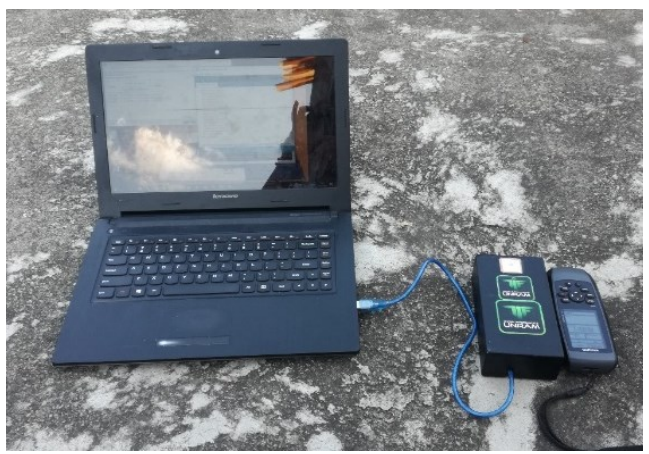

Gambar 11 Pengujian akurasi modul GPS

Dalam pengujian ini diambil 10 data sekaligus untuk posisi yang sama dengan jeda waktu penerimaan koordinat 1 menit. Pada Gambar 12 di bawah terlihat bahwa modul GPS memberikan informasi koordinat yang berbeda-beda namun posisinya mendekati dari posisi yang telah ditentukan.

Pada Gambar 12 di atas dapat dilihat data koordinat yang dihasilkan oleh modul GPS ditampilkan pada serial monitor software Arduino IDE. Untuk mengetahui berapa jarak error atau selisih antara koordinat dari yang asli dan koordinat dari yang diberikan oleh modul GPS dapat dihitung dengan Persamaan (1) [1].

$$
\mathrm{Z}=\sqrt{(B-A)^{2}+(D-C)^{2}}
$$

dimana Jarak Error $=Z$ X 111.322 kilometer

Ket: $\quad Z=$ nilai derajat

$A=$ nilai latitude yang sebenarnya

$\mathrm{B}=$ nilai latitude dari modul

$\mathrm{C}=$ nilai longitude yang sebenarnya

$\mathrm{D}=$ nilai longitude dari modul

1 derajat di maps $=111.322$ kilometer

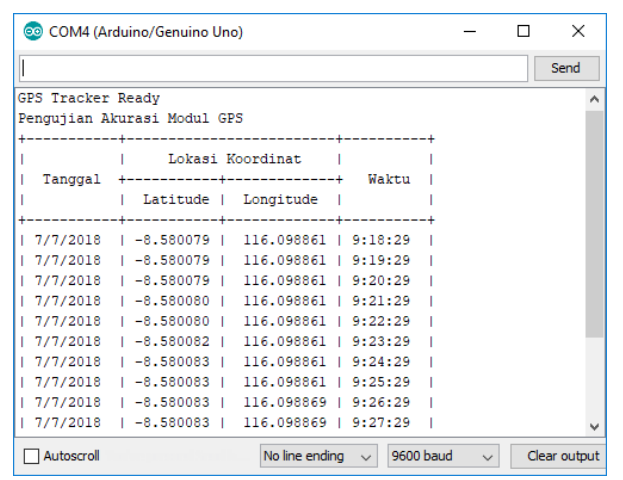

Gambar 12 Hasil pengujian akurasi modul GPS

Pada pengujian ini, semua data yang didapatkan dari modul akan dihitung jarak error-nya dengan rumus yang ada di atas. Sebagai contoh, perhitungan jarak error pada data pertama adalah sebagai berikut.

Diketahui:

Koordinat asli $=-8.580083,116.098860$

Koordinat modul $=-8.580079,116.098861$

Ditanyakan: Selisih jarak error $=\ldots$ ?

Maka:

$\mathrm{Z}=$

$\sqrt{(-8.580079-(-8.580083))^{2}+(116.098861-116.098860)^{2}}$

$=\sqrt{(0.000004)^{2}+(0.000001)^{2}}$

$=\sqrt{0.000000000017}$

$=0.00004123$ derajat

Jarak Error $\quad=0.00006007 \times 111.322$ kilometer $=0.00458$ kilometer $=4,58$ meter

Dari hasil perhitungan di atas, maka diketahui jarak selisih error pada data pertama yang diberikan oleh modul GPS GY-Neo6mv2 adalah berkisaran di angka 4,58 meter. Adapun hasil perhitungan selisih jarak error dari semua data yang diberikan oleh modul dapat dilihat pada Tabel 4.1.

Dari hasil pengujian pada tabel 4.1 di atas, didapatkan hasil selisih jarak error rata-rata adalah 2,457 meter dengan jarak terdekat adalah 0,11 meter dan jarak error terjauh adlah 4,58 meter. 
TABEL I. HASIL PENGUJIAN

\begin{tabular}{|l|l|l|c|}
\hline \multirow{2}{*}{ No. } & \multicolumn{2}{|l|}{ Koordinat } & \multirow{2}{*}{ Error $(\mathrm{m})$} \\
\cline { 2 - 3 } & Latitude & Longitude & \\
\hline 1 & -8.580079 & 116.098861 & 4,58 \\
\hline 2 & -8.580079 & 116.098861 & 4,58 \\
\hline 3 & -8.580079 & 116.098861 & 4,58 \\
\hline 4 & -8.580080 & 116.098861 & 3,52 \\
\hline 5 & -8.580080 & 116.098861 & 3,52 \\
\hline 6 & -8.580082 & 116.098861 & 1,57 \\
\hline 7 & -8.580083 & 116.098861 & 0,11 \\
\hline 8 & -8.580083 & 116.098861 & 0,11 \\
\hline 9 & -8.580083 & 116.098869 & 1,00 \\
\hline 10 & -8.580083 & 116.098869 & 1,00 \\
\hline \multicolumn{3}{|c|}{ jumlah seluruh selisih } & 2,457 \\
\hline \multicolumn{4}{|c|}{ rata - rata $=\frac{1,13 \text { seluruh data }}{}$} \\
\hline
\end{tabular}

\subsubsection{Pengujian Modul GPRS Sebagai Pengirim Data ke Web Server.}

Pada pengujian ini, alat dalam posisi tidak bergerak dan telah ditentukan posisinya yaitu pada posisi koordinat $-8.60997,116.10637$. Data yang dikirim untuk setiap posisi adalah ID dari perangkat GPS, latitude, dan longitude. Pengujian modul SIM/GPRS ini sendiri menggunakan jeda waktu pengiriman yang 10 detik dan 60 detik sebagai sampel.

Pada pengujian ini data yang dikirim oleh modul SIM/GPRS berhasil diterima oleh server sistem informasi pelacakan kendaraan bermotor. Data tersebut kemudian disimpan pada database server. Dapat dilihat pada Gambar 12, data yang diterima oleh server adalah berupa ID perangkat dari alat GPS yang telah ditentukan sebelumnya yaitu gps01 kemudian juga ada latitude dan longitude. Namun pada saat penerimaan data di pengujian ini masih terjadi erorr, hal ini disebabkan oleh beberapa faktor antara lainnya adalah koneksi GPRS pada modul SIM yang terganggu.

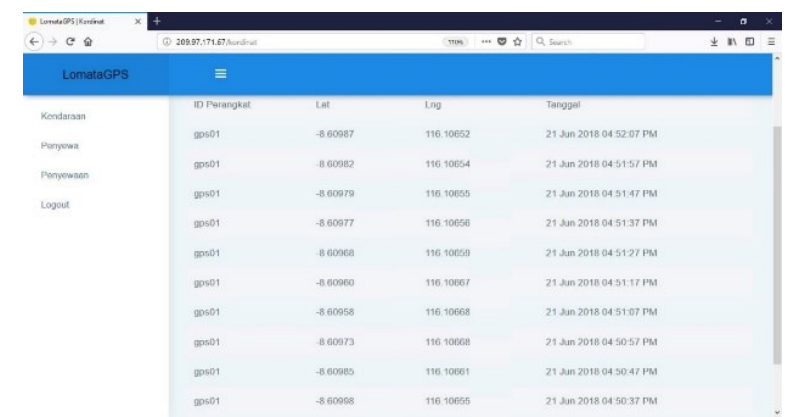

Gambar 13 Hasil pengujian pengiriman data ke web server

\subsubsection{Pengujian Fungsi Keseluruhan Perangkat GPS Tracker.}

Setelah pengujian modul GPS dan modul GSM/GPRS berhasil berjalan dengan baik dan sesuai dengan harapan saat diujikan, maka selanjutnya akan dilakukan pengujian terhadap fungsi perangkat GPS Tracker secara keseluruhan menggunakan pengujian ini metode yang digunakan adalah metode black box.

Pengujian fungsi keseluruhan ini dilakukan dengan cara memasang alat tersebut pada kendaraan bermotor. Kemudian alat akan disambungkan dengan step down converter $12 \mathrm{~V}$ to $5 \mathrm{~V}$ sebelum disambungkan langsung ke catu daya atau accu/aki kendaraan. Step down converter ini digunakan untuk menurunkan tegangan dari aki yang awalnya dari $12 \mathrm{~V}$ menjadi $5 \mathrm{~V}$ sehingga perangkat GPS tidak mengalami kerusakan yang disebabkan oleh daya yang diterima terlalu besar.

Setelah perangkat terpasang, kemudian kendaraan akan dijalankan keliling rute jalan yang telah ditentukan untuk menguji kemampuan dari perangkat GPS Tracker. Langkah terakhir dalam pengujian ini adalah dengan melihat hasil pelacakan kendaraan bermotor pada web sistem informasi kendaraan bermotor. Hasil dari pengujian fungsi keseluruhan dari perangkat GPS tracker dapat dilihat pada Gambar 14 dan Gambar 15 di bawah ini.

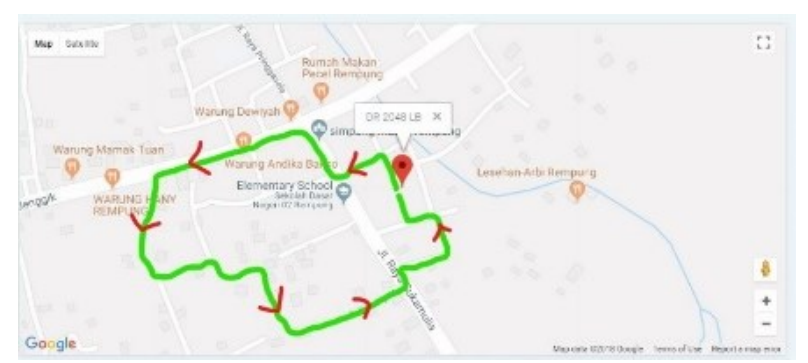

Gambar 14 Jalur sebenarnya yang dilewati kendaraan saat pengujian perangkat GPS Tracker.

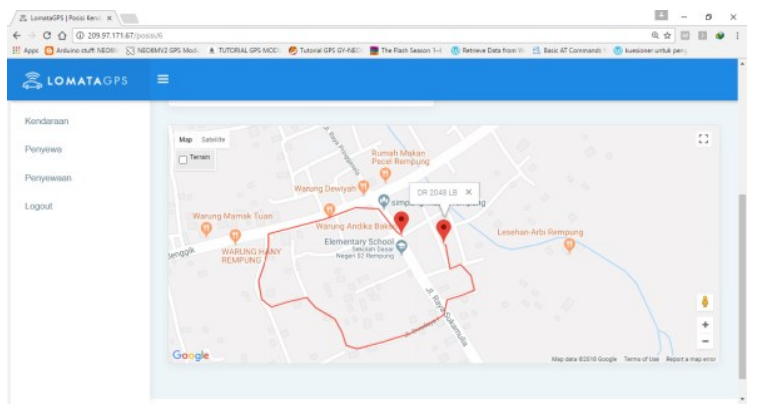

Gambar 15 Hasil rute yang dikirimkan perangkat GPS Tracker 
Pada Gambar 14 di atas adalah jalur yang sebenarnya dilewati pada saat pengujian perangkat GPS ini. Tanda panah merah pada gambar tersebut menandakan arah jalur yang dilewati. Sedangkan pada Gambar 15 adalah hasil rute yang dikirimkan oleh perangkat GPS tracker pada pengujian ini. Dapat dilihat jika dibandingkan dengan rute yang sebenarnya, pada menit-menit awal keberangkatan posisi kendaraan tidak tercatat pada web sistem informasi kendaraan bermotor dan tidak terdeteksi oleh perangkat GPS. Hal ini disebabkan oleh modul GPS GY Neo 6 mv2 yang membutuhkan waktu beberapa saat untuk dihidupkan dan perangkat ini membutuhkan waktu yang cukup lama untuk melakukan sinkronisasi dengan satelit sampai dapat memberikan data koordinat posisi dari kendaraan yang benar.

Pada pengujian ini juga akan diuji fungsi mengatur jarak pengiriman data dari web yaitu dengan cara mengambil data dari respons yang dihasilkan dari proses pengiriman data. Data dari repons ini nantinya akan digunakan untuk meng-update nilai interval jarak pengiriman data yang akan dikirim oleh perangkat GPS. Langkah pertama yang dilakukan adalah dengan menge-set nilai update interval dari kendaraan yang ada pada daftar kendaraan.

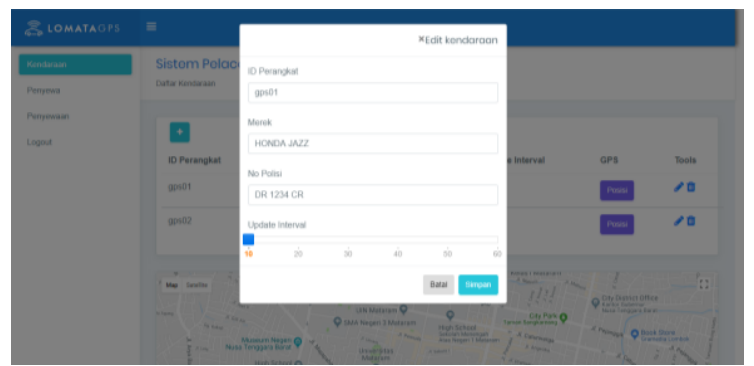

Gambar 16 menge-set nilai update interval 10 detik

Setelah mengeset nilai update interval, maka langkah selanjutnya ialah mengecek apakah data yang masuk pada database beserta jarak waktu delay pengiriman sesuai dengan apa yang telah di-set sebelumnya.

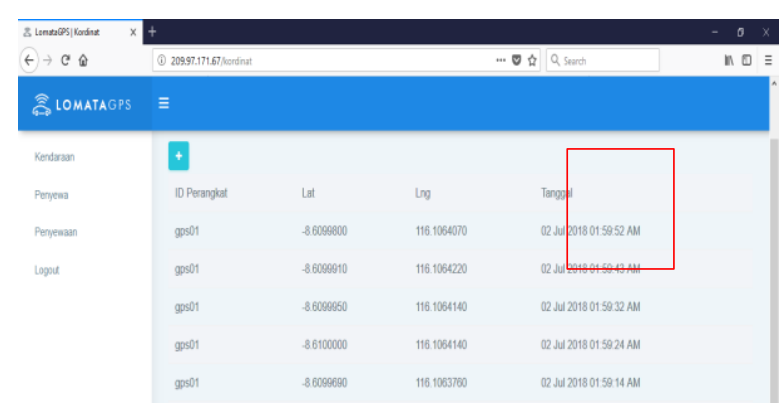

Gambar 17 mengecek nilai update interval 10 detik
Pada Gambar 17 di atas, dapat dilihat bahwa interval pengiriman data berjarak 10 detik walaupun terkadang terdapat error pengiriman beberapa detik yang disebabkan oleh koneksi sinyal GPRS yang terganggu.

Setelah mengecek data yang masuk pada database, langkah selanjutnya adalah merubah nilai update interval pengiriman delay kendaraan yang ada pada halaman daftar kendaraan. Nilai interval delay yang diinput adalah 60 detik.

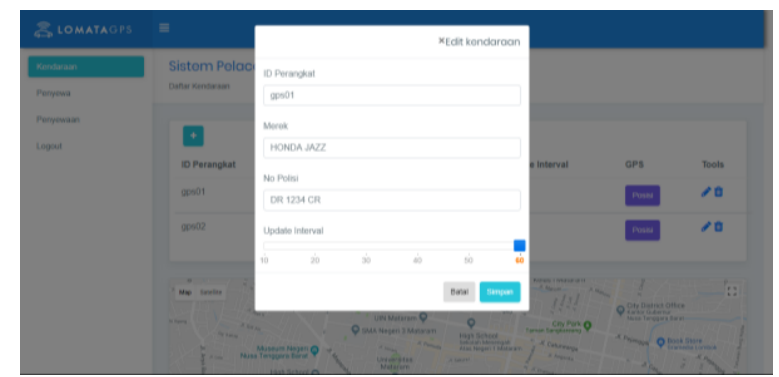

Gambar 18 menge-set nilai update interval 60 detik

Pada Gambar 18 nilai dari update interval sudah berhasil diubah dari 10 detik menjadi 60 detik. Kemudain langkah selanjutnya adalah mengecek apakah data yang masuk pada database dan interval delay pengiriman data sudah berhasil di-update.

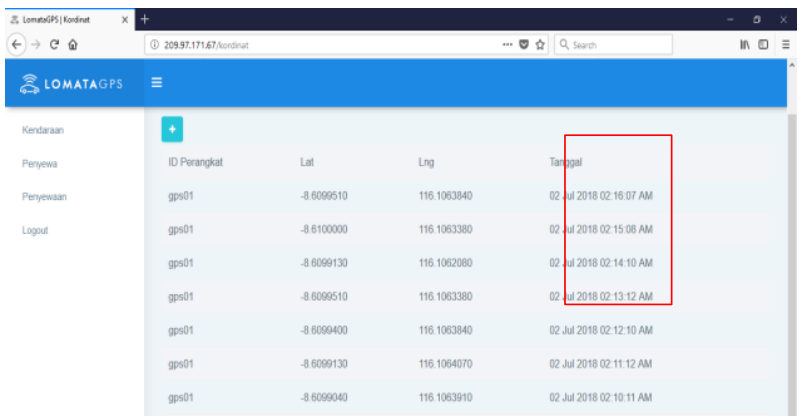

Gambar 19 Hasil nilai update interval delay pengiriman yang berhasil diubah

Pada Gambar 19 dapat dilihat bahwa jarak pengiriman berhasil diubah dari 10 detik menjadi 60 detik. Dengan hasil ini maka dapat dipastikan bahwa fungsi pengaturan interval pengiriman data yang dilakukan melalui web sistem informasi pelacakan kendaraan bermotor berhasil dilakukan.

\subsubsection{Hasil Pengujian Web Sistem Informasi Pelacakan Kendaraan Bermotor}

Pada pengujian web sistem informasi pelacakan kendaraan bermotor ini dilakukan dengan menggunakan 2 metode. Metode yang pertama adalah metode black box untuk menguji fungsi-fungsi yang 
ada di dalam sistem, kemudian metode yang kedua adalah metode Mean Opinion Score (MOS) yaitu pengujian dengan menggunakan kuesioner untuk memberikan penilaian dengan melibatkan pihak yang terkait dengan penelitian ini, yaitu user / admin dari web lomata GPS untuk menilai fungsionalitas sistem.

a. Hasil Pengujian Menggunakan Metode Black Box.

Pada pengujian menggunakan metode black box ini akan menguji fungsi-fungsi yang terdapat pada sistem informasi pelacakan kendaraan bermotor berbasis web sudah berjalan dengan sesuai harapan atau tidak. Berikut merupakan fungsi fungsi yang diuji.

1. Pengujian fungsi login user/admin.

2. Pengujian tambah daftar kendaraan.

3. Pengujian edit/update daftar kendaraan.

4. Pengujian hapus daftar kendaraan.

5. Pengujian melacak posisi terakhir kendaraan.

6. Pengujian memantau (tracking) kendaraan.

7. Pengujian penambahan penyewa.

8. Pengujian edit daftar penyewa.

9. Pengujian penambahan penyewaan.

10. Pengujian edit daftar penyewaan.

11. Pengujian fitur maps.

Dari semua hasil pengujian di atas menghasilkan kesimpulan valid yaitu semua fungsi yang diujikan sudah berjalan dengan baik sesuai yang dharapkan.

b. Hasil Pengujian Menggunakan Metode Mean Opinion Score (MOS).

Pengujian dengan menggunakan metode MOS ini dilakukan dengan cara mencari responden (dalam hal ini adalah para karyawan dari Lomata Tour \& Travel) untuk mencoba menjalankan sistem, lalu memberikan pertanyaan berupa kuesioner. Tujuan dari pengujian ini adalah mengetahui bagaimana kualitas sistem dilihat dari sisi pengguna.

Pengujian dilakukan kepada pihak user yang terkait dalam penelitian ini yaitu para admin dan karyawan dari Lomata Tour \& Travel yang berjumlah 5 orang. Adapun pertanyaan kuesioner yang diberikan adalah sebagai berikut:

1. Sistem Informasi Pelacakan Kendaraan Bermotor sudah dapat berjalan dengan baik dan sesuai dengan harapan?

2. Sistem Informasi Pelacakan Kendaraan Bermotor dapat memberikan informasi posisi kendaraan?

3. Fungsi penambahan daftar kendaraan, daftar penyewa dan daftar penyewaan kendaraan mudah dipahami dan digunakan?
4. Fungsi pelacakan posisi \& tracking kendaraan mudah digunakan?

5. Apakah sistem ini membantu / memudahkan perusahaan Lomata Tour and Travel untuk memantau lokasi kendaraan milik Lomata?

6. Interface Sistem Informasi Pelacakan Kendaraan Bermotor ini mudah dipahami dan digunakan (user friendly)?

Dengan menggunakan rumus perhitungan yang sudah dijelaskan, berikut hasil rekapitulasi data kuesioner dan persentase jawaban dari responden admin Lomata Tour and Travel:

TABEL II. HASIL KUESIONER

\begin{tabular}{|c|c|c|c|c|c|}
\hline \multirow{2}{*}{ Pertanyaan } & \multicolumn{5}{|c|}{ Pergentase } \\
\cline { 2 - 6 } & $\begin{array}{c}\text { Sangat } \\
\text { Setuju }\end{array}$ & Setuju & Cukup & $\begin{array}{c}\text { Tidak } \\
\text { Setuju }\end{array}$ & $\begin{array}{c}\text { Sangat } \\
\text { Tidak } \\
\text { Setuju }\end{array}$ \\
\hline 1 & $0 \%$ & $100 \%$ & $0 \%$ & $0 \%$ & $0 \%$ \\
\hline 2 & $0 \%$ & $100 \%$ & $0 \%$ & $0 \%$ & $0 \%$ \\
\hline 3 & $20 \%$ & $80 \%$ & $0 \%$ & $0 \%$ & $0 \%$ \\
\hline 4 & $0 \%$ & $100 \%$ & $0 \%$ & $0 \%$ & $0 \%$ \\
\hline 5 & $80 \%$ & $20 \%$ & $0 \%$ & $0 \%$ & $0 \%$ \\
\hline 6 & $0 \%$ & $100 \%$ & $0 \%$ & $0 \%$ & $0 \%$ \\
\hline Total & $16,67 \%$ & $83,33 \%$ & $0 \%$ & $0 \%$ & $0 \%$ \\
\hline
\end{tabular}

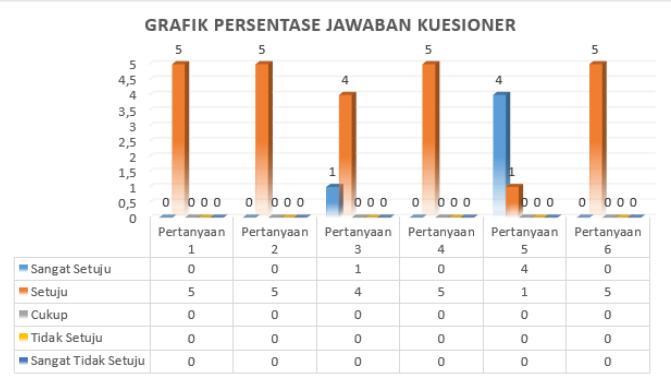

Gambar 20 Grafik jawaban kuesioner

Berdasarkan Tabel II dan Gambar 20 dapat dilihat untuk kesimpulan atau persentase terbesar dari keseluruhan jawaban responden terletak pada jawaban setuju yaitu sebesar 83,33\%. Sedangkan sisanya $16,67 \%$ memilih jawaban sangat setuju. Sehingga dapat disimpulkan bahwa sistem sudah berjalan sesuai dengan apa yang diharapkan oleh pihak Lomata Tour and Travel.

\section{KeSIMPULAN DAN SARAN}

\subsection{Kesimpulan}

Kesimpulan yang dapat diambil dari tugas akhir ini adalah sebagai berikut:

1. Sistem Informasi Pelacakan Kendaraan Bermotor menggunakan GPS Berbasis Web dapat diintegrasikan dengan API Google Maps yang kemudian menggunakan konsep dan arsitektur loT, 
dapat dibangun sebuah perangkat GPS Tracker menggunakan Arduino Uno R3 sebagai kontrol aplikasinya yang telah diintegrasikan dengan modul GPS sebagai penerima data koordinat lokasi dan modul GPRS sebagai pengirim data melalui internet ke web service yang disediakan oleh Sistem Informasi Pelacakan Kendaraan Bermotor.

2. Berdasarkan hasil pengujian akurasi modul GPS dengan posisi yang sebenarnya, didapatkan hasil bahwa selisih jarak error rata-rata adalah 2,457 meter dengan jarak selisih error terdekat adalah 0,11 meter dan jarak selisih error terjauh adalah 4,58 meter.

3. Berdasarkan pengujian, Modul GSM/GPRS berhasil mengirimkan lokasi koordinat yang didapatkan dari modul GPS ke database server sistem informasi melalui internet dengan menggunakan jaringan seluler

4. Selama proses tracking, titik-titik posisi yang didapat dari GPS akan membentuk sebuah rute perjalanan sehingga user dapat melihat secara realtime perubahan dari posisi kendaraan.

5. Penggunaan update interval delay digunakan untuk mengatur jeda antar pengiriman data yang dilakukan oleh perangkat GPS, sehingga jeda pengiriman data dapat diatur sesuai dengan keinginan pengguna.

\subsection{Saran}

Jika dilakukan penelitian lebih lanjut tentang penelitian ini dapat mempertimbangkan saran-saran sebagai berikut:

1. Sistem diharapkan dapat dikembangkan lebih lanjut dengan menggunakan sistem informasi berbasis mobile.

2. Sistem ini diharapkan dapat dikembangkan dengan menambahkan fitur cut engine atau mematikan kendaraan dari jarak jauh menggunakan internet

3. Sistem ini diharapkan bisa dikembangkan dengan menambahkan fitur history kendaraan, dimana riwayat perjalanan atau lokasi kendaraan dapat dilihat pada suatu waktu.

\section{DAFTAR PUSTAKA}

[1] S.P. Wijaya, Y. Christiyono, and Sukiswo., Alat Pelacak Lokasi Berbasis GPS Via Komunikasi Seluler, Universitas Diponegoro, Semarang, 2010.

[2] A. Pangestu, Sumardi, and Sudjadi, "Perancangan Alat Pengaman dan Tracking Kendaraan Sepeda Motor dengan Menggunakan Mikrokontroler ATMEGA644PA", Universitas Diponegoro, Semarang, 2014.

[3] E.D. Meutia, "Internet of Things - Keamanan dan Privasi" Universitas Syiah Kuala, Banda Aceh, 2015

[4] A. Nurhartono, "Perancangan Sistem Keamanan Untuk Mengetahui Posisi Kendaraan yang Hilang Berbasis GPS dan Ditampilkan Dengan Smartphone", Universitas Negeri Yogyakarta, Yogyakarta, 2015

[5] A.P. Bisma,"Sistem Keamanan Kendaraan Bermotor Menggunakan SMS dengan Metode GPS Tracking Berbasis Arduino", Universitas Islam Negeri Auluddin, Makassar, 2016

[6] Z.A. Hasanuddin, "Penentuan Posisi Dengan GPS dan Aplikasinya", Pranya Paramita, Jakarta, 2002

[7] Ecadio, "Mengenal Arduino Uno R3", 2016

[8] D. Masud, A.H., Ramhan, and M., Fitriani, "Ruangan Menggunakan Sensor Sidik Jari Berbasis Mikrokontroler Atmega328p" SENTIKA, Yogyakarta. 2014

[9] M.A. Kuswardayan, I. Hariadi, and R.R "Perancangan dan implementasi RESTful Web Service untuk Game Sosisal Food Merchant Saga pada Perangkat Android", Institut Teknologi Sepuluh Nopember (ITS), Surabaya, 2013

[10] R. Novina, "Pengenalan Frame Laravel," 2014

[11] I.F. Rizal, Rancang Bangun Digital Home Asistant Dengan Perintah Suara Menggunakan Raspberry Pi dan Smartphone", Universitas Mataram, Mataram. 2017 